\title{
Effect of density and propagation length on ultrasonic longitudinal wave velocity in some important wood species grown in Turkey
}

\author{
Tuğba Yılmaz Aydın a,", Murat Aydın ${ }^{\mathrm{b}}$
}

\begin{abstract}
In solids, density is an important factor that determines lots of properties such as mechanic behavior. Mechanic properties of materials can be determined by static and dynamic tests. Ultrasonic measurements are one of the non-destructive test methods and are being applied to lots of field for determination of wide range of properties. When literature in wood science reviewed, it's seen that researches did not make a consensus on the effect of density on ultrasonic wave velocity. Also, propagation length is another issue that has close relations with ultrasonic waves. From this point of view, effects of density and propagation length on ultrasonic longitudinal wave in Oriental beech, Scots pine, Black pine and Turkish red pine woods were investigated in this study. 20x20 cross-cut and 20,30 and 40mm L direction samples were used to perform measurements. All samples acclimatized at $20 \pm 1{ }^{\circ} \mathrm{C}$ temperature and $65 \%$ relative humidity. Then, ultrasonic measurements performed using OLYMPUS EPOCH 650 flaw detector and $2.25 \mathrm{MHz}$ contact type transducers. According to the results, MC of the samples were calculated around $12 \%$ and up to $25.49 \%$ increase in velocity observed when sample length increased from $20 \mathrm{~mm}$ to $40 \mathrm{~mm}$. Coefficients of determination between density and velocity were ranged from 0.78 to 0.94 . Therefore, it's concluded that both propagation length and density have positive effect on ultrasonic wave velocity in these woods.
\end{abstract}

Keywords: Ultrasonic, Oriental beech, Scots pine, Black pine, Turkish red pine, Density, Propagation length

\section{Türkiye'de yetişen bazı önemli ağaç türlerinde yoğunluk ve yayılım uzunluğunun ultrasonik dalga hızına etkisi}

\begin{abstract}
Özet: Yoğunluk, katılarda mekanik davranış gibi birçok özelliği belirleyen önemli bir etkendir. Malzemelerin mekanik özellikleri statik ve dinamik testlerle belirlenebilir. Ultrasonik ölçümler, tahribatsız test yöntemlerinden biridir ve birçok alanda birçok özelliğin belirlenmesinde uygulanmaktadır. Ahşap bilimindeki literatür incelendiğinde, ultrasonik dalga hızı üzerine yoğunluğun etkisi hakkında araştırmacıların ortak bir fikir ortaya koymadığı görülmektedir. Ayrıca, yayılım uzunluğu ultrasonik dalgalar ile yakından ilişki içinde olan bir diğer konudur. Bu bakış açısıyla, bu çalışmada yoğunluk ve yayılım uzunluğunun Doğu kayını, sarıçam, kızılçam ve karaçam odunlarındaki boyuna ultrasonik dalgaya etkisi araştırılmışır.20x20mm enine kesit ve L yönündeki uzunlukları 20, 30 ve $40 \mathrm{~mm}$ olan örnekler ölçümlerin gerçekleştirilmesinde kullanılmıştır. Tüm örnekler, $20 \pm 1^{\circ} \mathrm{C}$ sıcaklık ve $\% 65$ bağıl nemde iklimlendirilmiştir. Sonrasında ultrasonik ölçümler, OLYMPUS EPOCH 650 hata detektörü ve $2.25 \mathrm{MHz}$ frekanslı temaslı tip transdüserler kullanılarak gerçekleştirilmiştir. Sonuçlara göre, örneklerin rutubet içerikleri yaklaşık \%12 olarak hesaplanmıștır ve dalga hızında örnek boyu 20mm'den 40mm'e çıktığında \%25.49'luk bir artıș gözlenmiștir. Yoğunluk ile hız arasındaki belirleme katsayıları 0.78 ile 0.94 değerlerinde sıralanmıştır. Dolayısıyla, hem yayılım uzunluğu hem de yoğunluğun bu ağaçlardaki ultrasonik dalga hızına olumlu etkisi olduğu sonucuna varılmıştır.

Anahtar kelimeler: Ultrasonik, Doğu kayını, Sarıçam, Karaçam, Kızılçam, Yoğunluk, Yayılım uzunluğu
\end{abstract}

\section{Introduction}

Discovery of the piezoelectricity in $19^{\text {th }}$ century can be assumed as a milestone for the future developments on material testing. And, at the beginning of the $20^{\text {th }}$ century, measurement tools such as SONAR (Sound Navigation and Ranging) were unveiled as one of the very first applications of the tools uses the echo-ranging technique. This technique based on receiving the echoes of the transmitted sound signal to acoustic locating the underwater. By the development of technologies, non-destructive characterization of materials by sound transceiving can be used almost all fields. Ultrasonic method is one of the most common used non-destructive testing methods. And, according to Vun et al. (2006) not only sample preparation is not required for tests and applications is safe but also ease of use in terms of application time, attenuation, radiofrequency and domains provide wide area usage of ultrasonic testing.

Basic wave types which used to determine wood material properties were mass (longitudinal and transverse) or surface (Rayleigh, Lamb and Love) waves (Bucur, 2006). And, according to Björnberg (2014) longitudinal and transverse waves were most common used wave types which used in ultrasonic testing. Ultrasonic waves which used in industrial non-destructive testing and evaluation travels through a structural material or component and focuses to detect the flaws or discontinuities such as cracks

\footnotetext{
$\triangle$ a Isparta University of Applied Sciences, Faculty of Forestry, Department of Forest Industrial Engineering, 32260, Isparta, Turkey

b Isparta University of Applied Sciences, Keçiborlu Vocational School, Department of Furniture and Decoration, 32700, Isparta, Turkey

@ * Corresponding author (İletişim yazarı): tugbayilmaz@isparta.edu.tr

$\checkmark \quad$ Received (Geliş tarihi): 11.09.2018, Accepted (Kabul tarihi): 12.11.2018
}

Citation (Atıf): Aydın, T.Y., Aydın, M., 2018. Effect of density and propagation length on ultrasonic longitudinal wave velocity in some important wood species grown in Turkey. Turkish Journal of Forestry, 19(4): 413-418. DOI: $10.18182 /$ tjf.459005 
(Schmerr, 2007). According to Berke (2000) radiography and ultrasonic tests were some of the most common used methods for detection of invisible inner flaws. Ultrasonic techniques were one of the most suitable methods for determination of all elastic properties of any material (Musgrave, 1970; Hearmon, 1961; Dahmen et al., 2010). And, it's simple and very fast to perform measurements (Halachan et al., 2017).

Ultrasonic measurements can be performed by different propagation methods and according to UNI EN 14579 (2004) and Carcangiu et al. (2015) through transmission and pulse-echo were the most common used methods in ultrasonic testing, respectively. Some properties of these methods were expressed by Senalik et al. (2014) and they stated that locating the depth of a defect is possible in pulseecho mode but impossible in through transmission mode. According to Aziz et al. (2013) through transmission method was more suitable than pulse-echo method for ultrasonic testing of the materials which are porous and have rough fiber such as wood. But, many features of pulse-echo signals can be correlated with visible wood anatomical features (Berndt and Johnson, 1995). Lots of studies conducted to determine different properties of wood or wood based products using ultrasound but bonding test on plywood by Czerlinsky (1943) was assumed as one of the very first practices of ultrasonic testing (Krautkraemer and Krautkraemer, 1990).

Evaluation of ultrasonic measurements depends on some factors such as wood species and/or structure, testing parameters, propagation method and direction, environmental conditions, etc. Calegari et al. (2011) reported that moisture content and density are the main and second factors that affect the ultrasonic wave velocity, respectively. Gerhards (1982), Bucur (1983) and Mishiro (1996a) stated that effect of density on acoustic wave depends on species, structure and propagation direction. Effects of these factors were partially studied by different researchers. And no common idea about density effect on velocity was reported by researchers as followings. Baradit and Niemz (2011), Baar et al. (2012), Oliveira et al. (2005ab), Oliveira and Sales (2006) and Brandner et al. (2007) reported positive relations while Bucur and Chivers (1991) was negative. Besides, Mishiro (1996b), Oliveira et al. (2002), Ilic (2003) and Teles et al. (2011) reported neither positive nor negative relations between them. Also, Beall (2002) reported that effect of wood density on signal attenuation not clearly expressed. According to the Schmerr and Song (2007) reason of the attenuation of ultrasonic signal is so complex and amplitude of the signal decreases through the propagation path. Attenuation occurs with the distance and rises straightly with frequency (Cochran, 2012). Besides, moisture content, structure of the solid or tested material are some of the other influencing factors. In wood, attenuation generally occurs because of absorption (Krautkraemer and Krautkraemer, 1990).

Wood is a unique building material due to not only its environmental friendly characteristic such as being fully renewable and naturally grown properties (Menges et al., 2017) but also its unrivalled mechanic characteristics. Density is the key parameter which describes the mechanic characteristic of a material. In the direction of all the facts mentioned above, this study aimed to figure out the effects of density and propagation length on ultrasonic longitudinal wave in wood.

\section{Material and method}

\subsection{Material}

Three softwoods, Scots pine, Black pine and Turkish red pine and one hardwood, Oriental beech, species were used in this study. Defect-free, 20x20mm cross-cut and 20, 30 and $40 \mathrm{~mm} \mathrm{~L}$ direction test samples were prepared from the sapwood section of these woods. 20 samples for each propagation lengths of each species, totally 240 samples, were prepared.

\subsection{Method}

Samples were stored in a climate chamber which operated at $20 \pm 1{ }^{\circ} \mathrm{C}$ temperature and $65 \%$ relative humidity to reach around $12 \%$ moisture content (MC). At the end of about $8^{\text {th }}$ weeks, samples weight became constant and therefore acclimation ended. MC and density of samples were calculated according to TS 2471 (2005) and TS 2472 (2005), respectively. EPOCH 650 (Olympus, USA) ultrasonic flaw detector and contact type transducers (seen in Figure 1) which propagate $2.25 \mathrm{MHz}$ longitudinal wave were used to conduct measurements. Through transmission method, uses one transmitting and one receiving transducers, was chosen to obtain time values between transmitted and received signals. In this method, waves travel across the tested materials. Velocity of the ultrasonic wave was calculated using velocity-time relation as seen in equation (1).

$$
\mathrm{V}=\mathrm{L} / \mathrm{T}(\mathrm{m} / \mathrm{s})
$$

where; $\mathrm{V}$ is ultrasonic velocity, $\mathrm{L}$ and $\mathrm{T}$ are specimen length and measured time-of-flight values, respectively.

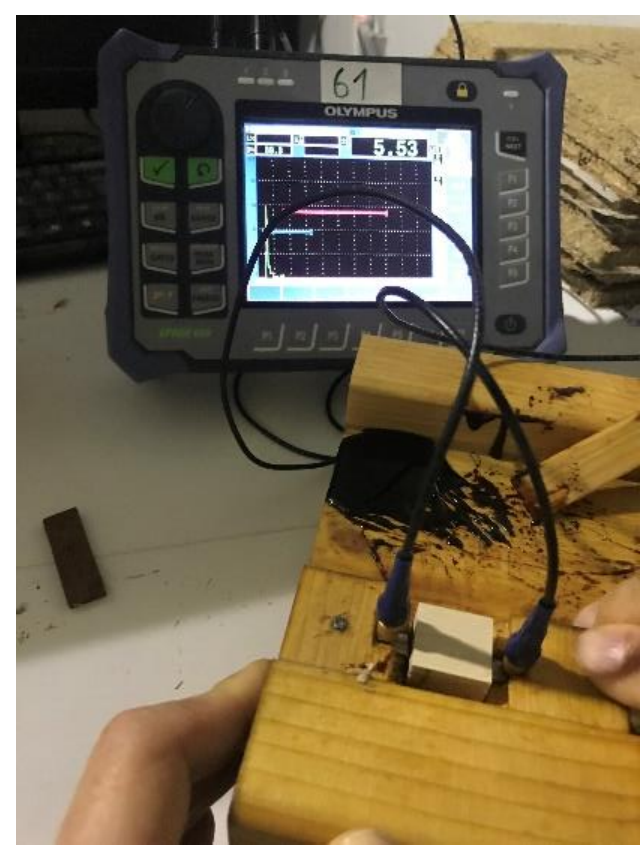

Figure 1. ToF measurements of ultrasonic longitudinal wave 


\section{Results and discussion}

In terms of propagation length, minimum, maximum, average and coefficient of variation $(\mathrm{V})$ values of the species moisture content, density and velocity were presented in Table 1. MC values of all test samples were ranged from $12.1 \%$ to $12.8 \%$. Coefficients of variation of all investigated properties were as low as possible. According to results, it's seen that velocities increased with the increase in propagation length. Densities were almost the same within the species in terms of length. Density values of the species were in accordance with the literature. Ultrasonic wave velocities of Scotch pine, Red pine, Black pine and Oriental beech wood were $14.21 \%, 14.1 \%, 25.49 \%$ and $12.70 \%$ increased when sample length increased from $20 \mathrm{~mm}$ to $40 \mathrm{~mm}$, respectively. In general increase amount of the velocity was around equal for all species expect Black pine. And, as seen in table maximum increase in velocity was observed for Black pine wood. Difference between Black pine and other softwoods is interesting and the reason of this differentiation should be clarified with further investigations.

Table 1. Moisture content, density and velocity values of samples

\begin{tabular}{|c|c|c|c|c|c|c|c|c|c|c|}
\hline & \multirow{2}{*}{$\begin{array}{l}\text { Propagation } \\
\text { length }(\mathrm{mm})\end{array}$} & \multirow{2}{*}{$\begin{array}{l}\text { M.C. } \\
(\%)\end{array}$} & \multicolumn{4}{|c|}{ Density $\left(\mathrm{g} / \mathrm{cm}^{3}\right)$} & \multicolumn{4}{|c|}{ Velocity (m/s) } \\
\hline & & & $\bar{x}$ & Min. & Max. & $\mathrm{V}(\%)$ & $\bar{x}$ & Min. & Max. & $\mathrm{V}(\%)$ \\
\hline \multirow{3}{*}{ Scotch pine } & 20 & 12.1 & 0.51 & 0.48 & 0.55 & 4.24 & 3784.19 & 3652.71 & 3973.88 & 2.38 \\
\hline & 30 & 12.2 & 0.51 & 0.47 & 0.56 & 5.26 & 4180.78 & 3956.13 & 4346.97 & 2.98 \\
\hline & 40 & 12.4 & 0.51 & 0.47 & 0.56 & 6.29 & 4322.25 & 4154.96 & 4466.52 & 2.13 \\
\hline \multirow{3}{*}{ Red pine } & 20 & 12.6 & 0.55 & 0.53 & 0.58 & 2.44 & 3656.95 & 3593.75 & 3719.93 & 0.94 \\
\hline & 30 & 12.3 & 0.54 & 0.52 & 0.56 & 2.42 & 3914.60 & 3799.24 & 4015.91 & 1.63 \\
\hline & 40 & 12.8 & 0.54 & 0.53 & 0.56 & 1.75 & 4172.69 & 4062.63 & 4314.38 & 1.53 \\
\hline \multirow{3}{*}{ Black pine } & 20 & 12.2 & 0.56 & 0.54 & 0.57 & 1.60 & 3652.40 & 3559.38 & 3759.79 & 1.47 \\
\hline & 30 & 12.4 & 0.54 & 0.50 & 0.59 & 5.69 & 4410.60 & 4009.20 & 5054.09 & 7.92 \\
\hline & 40 & 12.1 & 0.54 & 0.50 & 0.57 & 4.21 & 4583.76 & 4372.27 & 4838.55 & 3.16 \\
\hline \multirow{3}{*}{ Oriental beech } & 20 & 12.5 & 0.73 & 0.70 & 0.74 & 1.56 & 3780.99 & 3651.49 & 3869.72 & 1.64 \\
\hline & 30 & 12.3 & 0.73 & 0.71 & 0.77 & 2.15 & 4239.46 & 4021.05 & 4610.45 & 3.98 \\
\hline & 40 & 12.7 & 0.72 & 0.71 & 0.75 & 1.58 & 4261.22 & 4083.08 & 4488.89 & 3.12 \\
\hline
\end{tabular}
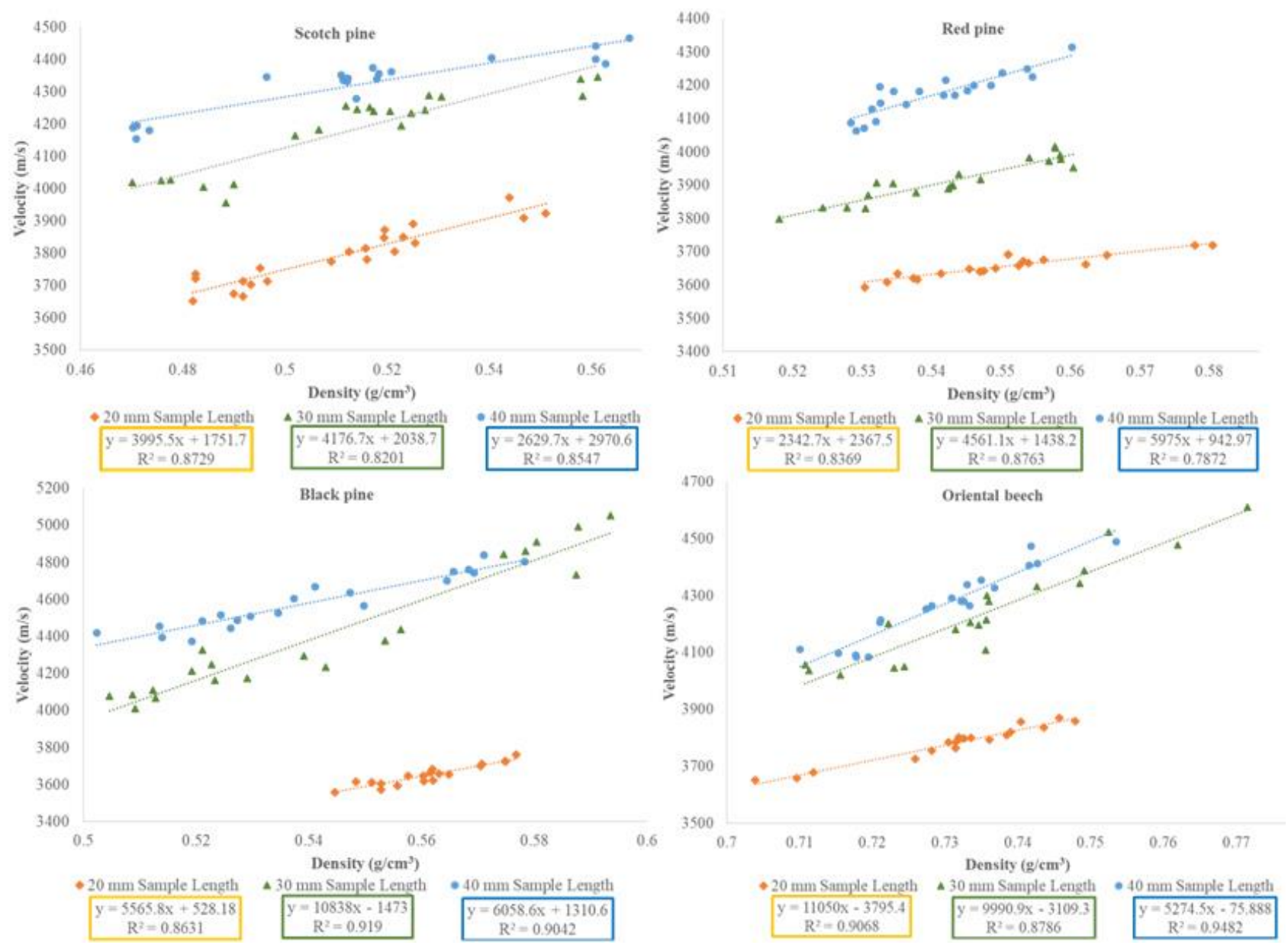

Figure 2. Relationships between ultrasonic velocity and density 
Relationships between density and velocity were presented in Figure 2. As seen in figure, there are positive relations between density and velocity for each propagation length groups of all species. And, slopes of the lines of all propagation length are different and upstream.

Correlations between density or propagation length and velocity were presented in Table 2 . As seen in table, there are statistically significant relations between all variables. Minimum coefficient ( $\mathrm{r}$ ) value $(0.830)$ obtained between velocity and propagation length in Black pine wood. Coefficient values ranged from 0.830 to 0.975 .

High frequency waves were used to evaluate the theory based correlation between wave velocity and density (Hearmon, 1965). Acoustic velocity and density are not independent from each other (Baar et al., 2012). And, according to Tomppo (2013) ultrasonic wave velocity in a solid primarily is affected by density and elasticity. Oliveira and Sales (2006) stated that ultrasonic wave velocity increased with the increase in density. Y1lmaz Aydın and Aydın (2018) reported approx. 9.97\% and $13.47 \%$ increase in velocity in Cedar wood (around $12 \% \mathrm{MC}$ ) when sample length increased from $20 \mathrm{~mm}$ to 30 and $40 \mathrm{~mm}$, respectively. And, variance analysis results proved that there was a statistically significant relation between propagation length and calculated velocity. They also reported a statistically significant correlation between density and velocity. Therefore, it's obvious that results of this study well agreed with aforementioned studies. On the contrary some studies reported opposing conclusions. Red pine, Mongolian pine and four other wood species were investigated by Hui et al. (2016). They obtained less than 0.24 coefficient of determination values and reported that longitudinal ultrasound velocity were independent on oven-dried density. In this study, $\mathrm{R}^{2}$ values within the species were ranged from 0.78 to 0.94 as seen in Figure 2. Therefore, as Palacios et al. (2011) stated, uniform, knot-free and un-interlocked grain test samples provided directly density dependent velocity values. Mishiro (1996b) and Ilic (2003) noted that density has not any effect on velocity. But according to Baar et al. (2012) suppression of the positive effect of density on velocity may be done by some factors such as macro and micro structure of the material. Calculated ultrasonic velocity values can be correlated to lots of factors such as $\mathrm{MC}$, density, growth ring angle, hardness, and strength as Miettinen and others (2005) did with using pine specimens. In this study just density and propagation length effects on velocity were evaluated. And, small and clear test samples were used. Íñiguez et al. (2007) used longer test samples prepared using Pinus sylvestris L. wood and reported that each 1 meter increase in sample length resulted $68 \mathrm{~m} / \mathrm{s}$ decrease in velocity in clear wood. In this sense, another study which investigates the effects of longer sample lengths up to meter is underway. Transmission or propagation of a wave in solids or materials depends on lots of factors such as chosen frequency, method, transducer type, set-ups of detector or signal generator, attenuation of signal, environmental conditions, material type and its structure, etc. Attenuation which is related to used frequency, propagation method of transducers and structure of test object is an important parameter in ultrasonic measurements (Berke, 2000). Therefore, matter of interpretation about measured values is getting a complex issue and due to these reasons skilled user required for ultrasonic testing and evaluation.

\section{Conclusion}

Properties of wood material depend on cellular anatomy of the wood structure. In this study longitudinal ultrasonic wave properties measured through the longitudinal direction of samples. L direction ultrasonic wave velocities calculated to evaluate wave-material interaction in terms of density and propagation length. Results showed that both density and propagation length had positive effects on velocity. Increase rate of velocity ranged from $12.7 \%$ to $25.49 \%$ in terms of sample length. In a same manner, increase in velocity observed when density of samples increased. Consequently, both density and sample length have positive relations to ultrasonic wave velocity in Scotch pine, Red pine, Black pine and Oriental beech wood. As an offer, a supplementary study which uses samples in a meter or longer dimensions should be evaluated to figure out whether there will be the similar results or not.

Table 2. Pearson correlation coefficients (r) between variables (Density, Velocity and Sample Length)

\begin{tabular}{|c|c|c|c|c|c|}
\hline \multirow{2}{*}{\multicolumn{2}{|c|}{ Species }} & \multicolumn{3}{|c|}{ Density } & \multirow{2}{*}{ Length } \\
\hline & & $2 \mathrm{~cm}$ Samples & $3 \mathrm{~cm}$ Samples & 4cm Samples & \\
\hline Scots pine & \multirow{4}{*}{ Velocity } & $0.949 * *$ & $0.895 * *$ & $0.925 * *$ & $0.880^{* * *}$ \\
\hline Red pine & & $0.910 * *$ & $0.938 * *$ & $0.849 * *$ & $0.968 * *$ \\
\hline Black pine & & $0.920 * *$ & $0.964 * *$ & $0.947 * *$ & $0.830 * *$ \\
\hline Beech & & $0.975 * *$ & $0.953 * *$ & $0.953 * *$ & $0.873^{* *}$ \\
\hline
\end{tabular}




\section{References}

Aziz, S.H., Shaari, A., Hafzan, S., Ahmad, M.N., İbrahim, A., Abidin, İ.M.Z., 2013. Elastic studies of tropical wood by using non-destructive ultrasonic technique. Proceedings of Malaysia International NDT Conference and Exhibition, 16-18 June 2013, Kuala Lumpur, Malaysia, pp. 1.

Baar, J., Tippner, J., Gryc, V., 2012. The influence of wood density on longitudinal wave velocity determined by the ultrasound method in comparison to the resonance longitudinal method. European Journal of Wood and Wood Products, 70(5): 767-769.

Baradit, E., Niemz, P., 2011. Selected physical and mechanical properties of Chilean wood species Tepa, Olivillo, Laurel, Lenga, Alerce and Manio. Proceedings of 17th Symposium Nondestructive Testing of Wood,14-16 September 2011, Sopron, Hungary, pp. 395-401.

Beall, F.C., 2002. Overview of the use of ultrasonic technologies in research on wood properties. Wood Sci. Technol., 36: 197-212.

Berke, M., 2000. Nondestructive material testing with ultrasonics. https://www.ndt.net/article/v05n09/berke/ berke1.htm, Accessed: 06.02.2017.

Berndt, H., Johnson, G.C., 1995. Examination of wave propagation in wood from a microstuructural perspective. In: Thompson, D.O., Chimenti, D.E., (Eds), Review of Progress in Quantitative Nondestructive Evaluation Volume 14, Plenum Press, New York, USA, pp 1661-1668.

Björnberg, J., 2014. Comparison of non-destructive techniques to discover defect finger joints in furniture. BSc thesis, Linnaeus University, Växjö, Sweeden.

Brandner, R., Gehri, E., Bogensperger, T., Schickhofer, G., 2007. Determination of modulus of shear and elasticity of glued laminated timber and related examinations. Proceedings of International Council for Research and Innaovation in Building and Construction Working Commission W18, August 2007, Bled, Slovenia, pp. 4012-2.

Bucur, V., 1983. An ultrasonic method for measuring the elastic constants of wood increment cores bored from living tress. Ultrasonics, 21: 116-126.

Bucur, V., 2006. Acoustics of Wood. Springer-Verlag, Heidelberg, Germany.

Bucur, V., Chivers, R.C., 1991. Acoustic properties and anisotropy of some Australian wood species. Acta Acustica united with Acustica, 75(1): 69-74.

Calegari, L., Gatto, D., Stangerlin, D., 2011. Influence of moisture content, specific gravity and specimen geometry on the ultrasonic pulse velocity in Eucalyptus grandis hill ex maiden wood. Ciência da Madeira, 2(2): 64-74.

Carcangiu, S., Montisci, A., Usai, M., 2015. Modeling ultrasounds for nondestructive testing applications. In: Burrascano, S. Callegari, A. Montisci, M. Ricci, and V. Mario, P., (Eds), Ultrasonic Nondestructive Evaluation Systems: Industrial Application Issues, Springer International, Switzerland, pp. 47-82.
Cochran, S., 2012. Piezoelectricity and basic configurations for piezoelectric ultrasonic transducers, In: Nakamura, K., (Ed), Ultrasonic Transducers: Materials and Design for Sensors, Actuators and Medical Applications. Woodhead Publishing, Cambridge, England, pp. 3-35.

Czerlinsky, E., 1943. Non-destructive plywood testing with ultrasound. Dt. Luftfahrtforschung, Deutschland, Unters. u. Mitt. Nr. 1042.

Dahmen, S., Ketata, H., Ben Ghozlen, M.H., Hosten, B., 2010. Elastic constants measurement of anisotropic Olivier wood plates using air-coupled transducers generated Lamb wave and ultrasonic bulk wave. Ultrasonics, 50(4-5): 502-507.

Gerhards, C.C., 1982. Longitudinal stress waves for lumber stress grading: factors affecting applications: state of art. Forest Products Journal, 32: 20-25.

Halachan, P., Babiak, M., Spišiak, D., Chubinsky, A.N., Tambi, A.A., Chauzov, K.V., 2017. Physico-acoustic characteristics of spruce and larche wood. Wood Research. 62: 235-242.

Hearmon, R.F.S., 1961. An Introduction to Applied Anisotropic Elasticity. Oxford University Press, Oxford, England.

Hearmon, R.F.S., 1965. The assessment of wood properties by vibrations and high frequency acoustic waves. Proceedings of 2nd Symposium Nondestructive Testing of Wood. April 1965, Pullman, WA. pp. 49-65.

Hui, P., Jiali, J., Tianyi, Z., Jianxiong, L., 2016. Influence of density and moisture content on ultrasound velocities along the longitudinal direction in wood. Scienta Silvae Sinicae, 52(10): 117-124.

Ilic, J., 2003. Dynamic MOE of 55 species using small wood beams. Holz als Roh und Werkstoff, 61(3): 167172.

Íñiguez, G., Esteban, M., Arriaga, F., Bobadilla, I., and Gil, M., 2007. Influence of specimen length on ultrasound wave velocity. Proceedings of 15 th International Symposium on Nondestructive Testing of Wood, 10-12 September 2007, Duluth, USA, pp. 155-159.

Krautkraemer, J., Krautkraemer, H., 1990. Ultrasonic Testing of Materials. Springer-Verlag, Berlin, Germany.

Menges, A., Schwinn, T., Krieg , D., 2017. Advancing wood architecture: an introduction. In: Achim, M., Tobias, S., Oliver, D.K., (Eds.), Advancing Wood Architecture A computational approach, Routledge, N.Y., U.S.A., pp.1-9.

Miettinen, P., Tiitta, M., Lappalainen, R., 2005. Electrical and ultrasonic analysis of heat-treated wood. Proceedings of 14th Symposium Nondestructive Testing of Wood. 2-4 May 2005, Eberswalde, Germany. pp. 265-274.

Mishiro, A., 1996a. Effects of grain and ring angles on ultrasonic velocity in wood. Mokuzai Gakkaishi, 42: 211-215.

Mishiro, A., 1996b. Effect of density on ultrasonic velocity in wood. Mokuzai Gakkaishi, 42(9): 887-894.

Musgrave, M.J., 1970. Crystal Acoustics: Introduction to The Study of Elastic Waves and Vibrations in Crystals. Acoustical Society of America, San Francisco, U.S.A.

Oliveira, F.G.R., de Campos, J.A., Pletz, E., Sales, A., 2002. Nondestructive evaluation of wood using ultrasonic techniques. Maderas Ciencia y Tecnologia, 4: 133-139. 
Oliveira, F.G.R., Candian, M., Lucchette, F.F., Salgon J.L., Sales, A., 2005a. A technical note on the relationship between ultrasonic velocity and moisture content of Brazilian hardwood (Goupia glabra). Building and Environment, 40(2): 297-300.

Oliveira, F.G.R., Candian, M., Lucchette, F.F., Salgon, J.L., Sales, A., 2005b. Moisture content effect on ultrasonic velocity in Goupia Glabra. Materials Research, 8(1): 11-14.

Oliveira, F.G.R., Sales, A., 2006. Relationship between density and ultrasonic velocity in Brazilian tropical woods. Bioresource Technology, 97(18): 2443-2446.

Palacios, P.I.C., Yoza, L.Y., Mallque, M.A., 2011. Elasticity modulus in Peruvian tropical woods using nondestructive techniques-preliminary study. Proceedings of 17th Symposium Nondestructive Testing of Wood, Vol. 2. 14-16 September 2011, Sopron, Hungary. pp. 469-475.

Schmerr, L., 2007. Fundamental models and measurements for ultrasonic nondestructive evaluation systems. In: Chen, C., (Ed), Ultrasonic and Advanced Methods for Nondestructive Testing and Material Characterization, World Scientific Publishing, Singapore, pp. 684.

Schmerr, L., Song,S., 2007. Ultrasonic Nondestructive Evaluation Systems Models and Measurements. Springer-Verlag, New York, U.S.A.

Senalik, C., Schueneman, G., Ross, R., 2014. Ultrasonicbased nondestructive evaluation methods for wood a primer and historical review. https://www.fpl. fs.fed.us/documnts/fplgtr/fpl_gtr235.pdf, Accessed: 16.05.2018
Teles, F., Del Menezzi, C., de Souza, F., Souza, M., 2011. Nondestructive evaluation of a tropical hardwood: Interrelationship between methods and physicalacoustical variables. Ciência da Madeira, 2(1): 1-14.

Tomppo, L., 2013. Novel applications of electrical impedance and ultrasound methods for wood quality assessment. Ph.D. dissertation, University of Eastern Finland, Kuopio, Finland.

TS 2471, 2005. Wood-Determination of moisture content for physical and mechanical tests. Turkish Standards Institution, Ankara.

TS 2472, 2005. Wood-Determination of density for physical and mechanical tests. Turkish Standards Institution, Ankara.

UNI EN 14579, 2004. Natural stone test methodsdetermination of sound speed propagation. International Organization for Standardization, Geneva.

Vun, R.Y., Eischeid, T., Bhardwaj, M.C., 2006. Quantitative non-contact ultrasound testing and analysis of materials for process and quality control. European Conference on NDT, https://www.ndt.net/article/ecndt2006/doc/ Th.3.7.2.pdf, Accessed: 06.03.2018.

Yılmaz Aydın, T., Aydın, M., 2018. Relationship between density or propagation length and ultrasonic wave velocity in cedar (Cedrus libani) wood. Proceedings of International Science and Technology Conference, 1820 July 2018, Paris, France, pp. 118. 